Available online at GSC Online Press Directory

GSC Biological and Pharmaceutical Sciences

e-ISSN: 2581-3250, CODEN (USA): GBPSC2

Journal homepage: https://www.gsconlinepress.com/journals/gscbps

(CASE STUdY)

\title{
The phytoremediation of Echinodorus palaefolius (Water Jasmine) in reducing BOD and COD of liquid waste - Batik Industry "X" in Pekalongan
}

\author{
Fitriani Nur and Isworo Slamet* \\ Departemen of Environemental Health. Faculty of Health. Universitas Dian Nuswantoro Semarang, Indonesia.
}

Publication history: Received on 20 September 2020; revised on 28 September 2020; accepted on 30 September 2020

Article DOI: https://doi.org/10.30574/gscbps.2020.12.3.0303

\begin{abstract}
The "X" batik industry is a textile industry with industrial waste water discharged into water bodies which causes high pollution in the Lodji river. Data from the Environmental Office of Pekalongan on the status of biological oxygen demand (BOD) and chemical oxygen demand (COD) in the Lodji River are classified as high, namely between $2.741-1.464 \mathrm{mg} / \mathrm{l}$, exceeding the quality standard $<45 \mathrm{mg}$. Phytoremediation technology is an effort to reduce Biological Oxygen Demand and Chemical Oxygen Demand pollutants. This study aims to determine the ability of phytoremediation with Enchinodorus palaefolius (water jasmine) in reducing levels of biological oxygen demand and chemical oxygen demand in batik industrial wastewater " $\mathrm{X}$ ". The method used is a quasi experiment with a non-equivalent control group design approach. Analysis of biological oxygen demand and chemical oxygen demand content using the analytical titration method. The Biological Oxygen Demand degradation modeling in treatment $1 \mathrm{~kg}, \mathrm{y}=-540.13 \mathrm{x}+2495.6$, treatment $0.75 \mathrm{~kg}, \mathrm{y}=-525.3 \mathrm{x}+1938.7$, treatment $0.5 \mathrm{~kg} \mathrm{y}=-515.09 \mathrm{x}+1923$ while modeling for chemical oxygen demand reduction in treatment $1 \mathrm{~kg}, \mathrm{y}=-2543.7 \mathrm{x}+10130$, treatment $0.75 \mathrm{~kg}, \mathrm{y}=-2500.7 \mathrm{x}+9913.8$, treatment $0.5 \mathrm{~kg}, \mathrm{y}=-$ $2578 x+10045$ Echinodorus palaefolius (water jasmine) was able to reduce Biological Oxygen Demand and Chemical Oxygen Demand levels by linear modeling on biological oxygen demand parameters with the best results on $0.5 \mathrm{~kg}$ treatment and chemical oxygen demand in $1.0 \mathrm{~kg}$ treatment.
\end{abstract}

Keywords: Phytoremediation; Echinodorus palaefolius; Biological oxygen demand; Chemical oxygen demand; Degradation; Linear modeling

\section{Introduction}

The city of Pekalongan is a city known as the biggest batik producing city in Central Java. Most of the people of Pekalongan City depend for their livelihoods as batik craftsmen. Besides having a positive impact on the economy of Pekalongan, it has a negative impact, especially in disrupting the ecological stability in the waters. [1] This is due to a large number of batik industries in Pekalongan that does not pay attention to the ecological balance of the environment which causes water resources to decline. Other problems that arise due to increased anthropogenic activity in Indonesia, which then affects the waste produced every day, such as domestic waste, livestock waste, agriculture, and industrial waste, are disposed of directly into water bodies without being treated first. [2]

Liquid waste from the waste products of the batik industry that enter water bodies will affect the quality of the water. Batik Industry " $X$ " in Pekalongan City is an industry engaged in textiles, located in the center of Pekalongan City, Central Java. This company was founded in 1970 with a production capacity of 3 million pieces per year. From the process of making batik, of course, it produces quite a large amount of liquid waste, especially from the nglorod process, namely the process of releasing the entire wax (wax) by inserting a cloth that is old enough in color to boil water, in this process

\footnotetext{
${ }^{*}$ Corresponding author: Fitriani Nur dan Isworo Slamet

Departemen of Environemental Health. Faculty of Health. Universitas Dian Nuswantoro Semarang, Indonesia. 
it produces liquid waste which is mostly disposed of into water bodies, thus disturbing the quality of surface water [3]. The large number of textile industries that dispose of their waste into surface water causes high pollution in the Lodji River in Pekalongan City [4]. The status of BOD and COD in the loji river was quite high, namely the value of color concentration, COD, TDS, and the $\mathrm{pH}$ of the remaining water from tilapia dye were $8047.5 \mathrm{mg} / \mathrm{L}, 6697.5 \mathrm{mg} / \mathrm{L}, 22100$ $\mathrm{mg} / \mathrm{L}$, and respectively. 12.163 while the dark blue dye content was $6.698 \mathrm{mg} / \mathrm{L}, 157104 \mathrm{mg} / \mathrm{L}, 11700 \mathrm{mg} / \mathrm{L}$, and 12.567, respectively. The values of all tested parameters of the two dyes exceed the textile industry wastewater quality standards according to the Regional Regulation of the Province of Central Java Number 5 of 2012 concerning Wastewater Quality Standards and Government Regulation Number 82 of 2001 dated 14 December 2001 concerning Water Treatment and Quality. Water pollution control. [5]

The ministerial regulation governing the feasibility of water, namely the Regulation of the Minister of Environment of the Republic of Indonesia Number 05 of 2014 concerning Wastewater Quality Standards which outlines a maximum BOD of $60 \mathrm{mg} / \mathrm{L}$ and a maximum COD of $150 \mathrm{mg} / \mathrm{L}$. The COD (chemical oxygen demand) is the amount of oxygen needed to break down all the chemicals contained in water, while BOD (biological oxygen demand) is the amount of oxygen needed by microorganisms to oxidize chemical compounds. The high value of COD (chemical oxygen demand) will result in a lack of oxygen content in the water so that it can disrupt aquatic ecosystems [6]. Therefore, BOD (biological oxygen demand) and COD (chemical oxygen demand) must meet predetermined thresholds. Efforts are made to reduce waste pollution by means of phytoremediation. [7]

Phytoremediation is the ability of plants to absorb organic and inorganic pollutants or other compounds found in waste. Phytoremediation technology, namely the water jasmine (Enchinodorus palaefolius). Water jasmine (Echinodorus palaefolius) is an aquatic plant that is able to absorb pollutants well. This is influenced by several factors, namely the root system. The roots of the water jasmine plant (Echinodorus palaefolius) lie at the bottom of the water, reproduction is flexible, strong, long, and spreading. [8]. The high number of cases of water contamination that occurs in rivers due to batik waste, phytoremediation is believed to be able to solve the problem of environmental pollution. Besides being effective and relatively cheap, phytoremediation is also environmentally friendly.[9]

Based on observations that have been made in the batik industry "X" Pekalongan has a simple wastewater treatment plant only in the form of a settling pond, then liquid limbs are flowed directly into the water body (loji river). This study aims to determine "the Phytoremediation Ability of Water Jasmine Plants (Echinodorus palaefolius) in Reducing Biological Oxygen Demand (BOD) and Chemical Oxygen Demand (COD) of Liquid Waste in Batik X Industry in Pekalongan".

\section{Research methods}

The type of research used in this study is a quasi experiment with a non-equivalent control group design approach.

\subsection{Place and time of research}

This research was conducted in August-September 2020 in the laboratory of Environmental Agency of Pekalongan, Central Java.

\subsubsection{Research Tools and Materials}

Toll

a. Plastic bucket: filling of batik industrial wastewater and sample of test plants. b. Scales: Weighing the test plant sample used. c. Winkler bottle: examination of BOD and COD levels in batik industrial wastewater.d. 4. Observation sheet: record the parameters of the research results. 5. Label paper: provide a description of the sample.

\subsubsection{Material}

1. Batik liquid waste: object of research. 2. Echinodorus palaefolius

(Water Jasmine): phytoremediator agent to reduce BOD levels in batik industrial wastewater 3. Stationery: record research data and documentation 


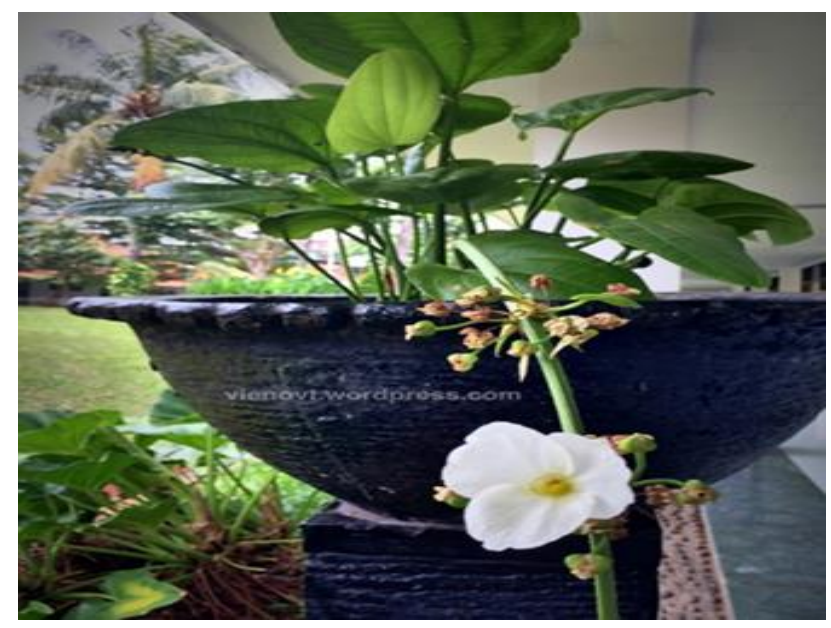

Figure 1 Echinodorus palaefolius (Water Jasmine) plant

\subsection{Data Collection Techniques}

The data collection technique in this study was carried out by observation through several stages of research procedures. The stages carried out in this study were divided into 2 groups, namely: the pre-research and research stages, as follows:

\subsection{Pre-research (Preparation Stage)}

Preparation stage of water jasmine (Echinodorus palaefolius). The water jasmine plants (Echinodorus palaefolius) which will be used in this study are taken in the rice fields, then the acclimatization process is carried out for 1 week. After the acclimatization process, water jasmine plants (Echinodorus palaefolius) were weighed with a weight of $1 \mathrm{~kg}, 0.75 \mathrm{~kg}, 0.5$ $\mathrm{kg}$ for various needs in the study. This acclimatization process aims to allow plants to adapt or adapt to new environments. The planting media used in this study were batik and soil industrial wastewater, $1.5 \mathrm{~kg}$ of soil used for each treatment, then put into the plastic buckets that had been provided.

\subsection{Preparation Stage of batik industry liquid waste}

The batik industrial liquid waste used in this research is taken from one of the batik industries in the city of Pekalongan. The batik industrial liquid waste is taken using a container and then taken to the research location and filled in $1 \mathrm{~L}$ of plastic buckets that have been provided for each treatment.

\subsubsection{Research (Phytoremediation Process)}

The water jasmine (Echinodorus palaefolius) has been transferred to plastic buckets that already contain planting media, namely soil and batik industrial wastewater. Water jasmine (Echinodorus palaefolius) is used based on the weight of the plant that has been determined. Test of BOD levels in batik industry liquid waste sample Before and after treatment the research parameters were measured, namely: BOD and COD (mg / L) by titration method.[10].

\section{Results and discussion}

Based on the results of measurement of BOD and COD in the phytoremediation process with the phytoremediation agent Water jasmine (Echinodorus palaefolius), are as follows: 
Table 1 Results of measurement of BOD and COD in the phytoremediation process

\begin{tabular}{|c|c|c|c|c|}
\hline \multicolumn{5}{|c|}{ The results of the measurement of the average BOD value } \\
\hline & Control (mg/l) & Day $2(\mathrm{mg} / \mathrm{l})$ & Day $4(\mathrm{mg} / \mathrm{l})$ & Day $6(\mathrm{mg} / \mathrm{l})$ \\
\hline Treatment (1 kg) & 1765.91 & 362.02 & 357.68 & 16.35 \\
\hline Treatment $(0.75 \mathrm{~kg})$ & 1765.91 & 362.02 & 368.08 & 46.92 \\
\hline Treatment (0.5 kg) & 1765.91 & 1554.52 & 1165.76 & 95.07 \\
\hline \multicolumn{5}{|c|}{ The results of the measurement of the average COD value } \\
\hline & Control (mg/l) & Day $2(\mathrm{mg} / \mathrm{l})$ & Day $4(\mathrm{mg} / \mathrm{l})$ & Day $6(\mathrm{mg} / \mathrm{l})$ \\
\hline Treatment (1 kg) & 9861.4 & 1746.95 & 1413.43 & 1379.14 \\
\hline Treatment $(0.75 \mathrm{~kg})$ & 9861.4 & 2086.04 & 1585.83 & 1549.26 \\
\hline Treatment (0.5 kg) & 9861.4 & 1654.83 & 1581.32 & 1550.11 \\
\hline
\end{tabular}

Hasil pengukuran BOD dan COD dianalisa dengan menggunakan Mocrosoft excel Trendline regresi linier untuk mengetahui trend evaluasi Degradasi Konsentrasi BOD dan COD pada prediksi waktu tertentu, sebagai berikut (figure 2 dan figure 3 )

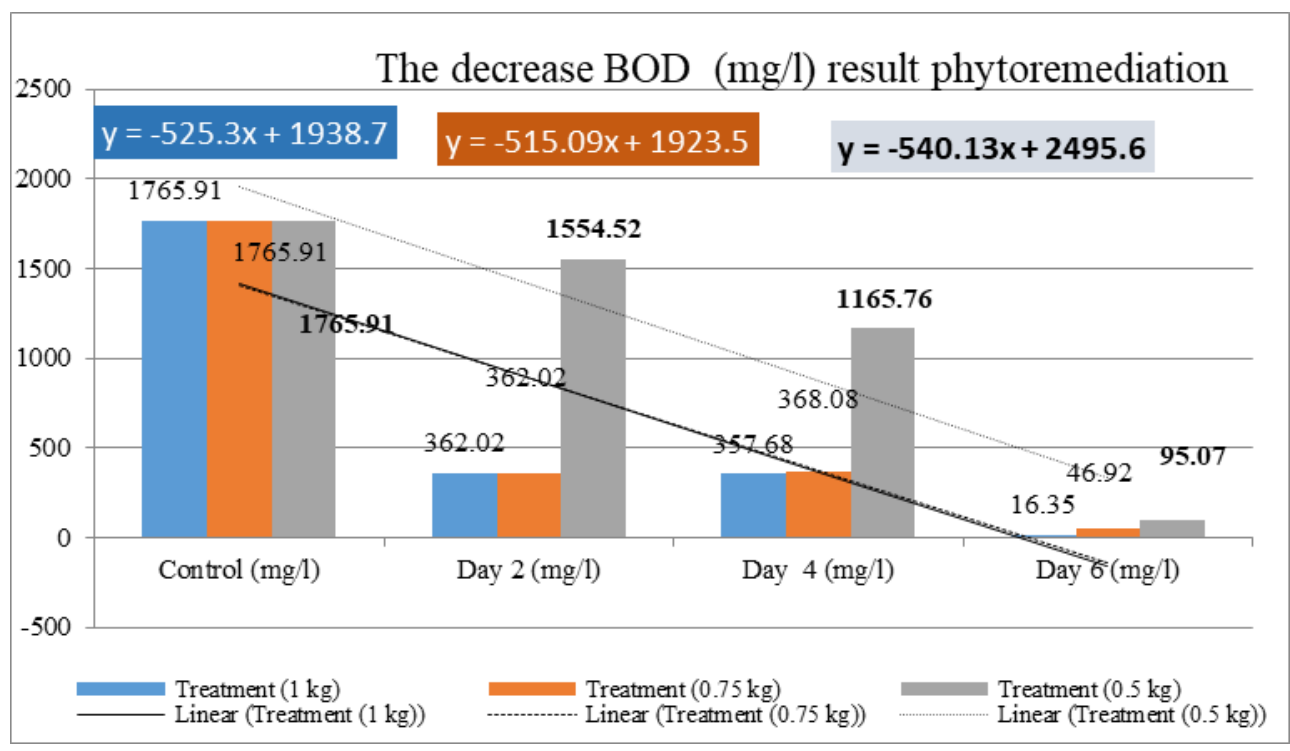

Figure 2 Trend evaluation decrease BOD (mg/l) result phytoremediation

The results of the BOD parameter phytoremediation modeling at $1 \mathrm{~kg}$ treatment have a linear equation is $\mathrm{y}=-525.3 \mathrm{x}$ +1938.7 , phytoremediation modeling on treatment $0.75 \mathrm{~kg}$ has a linear equation is $\mathrm{y}=-515.09 \mathrm{x}+1923.5$, phytoremediation modeling on $0.5 \mathrm{~kg}$ treatment the linear equation is $\mathrm{y}=-540.13 \mathrm{x}+2495.6$. Based on all models, it has a negative value, which shows that the Phytoremediation test of Echinodorus palaefolius (Water Jasmine) has succeeded in reducing the BOD concentration, in fig 2 all treatments showed a decreasing graph. The best regression modeling results are at $0.5 \mathrm{~kg}$ treatment with the equation $\mathrm{y}=-540.13 \mathrm{x}+2495.6$. 


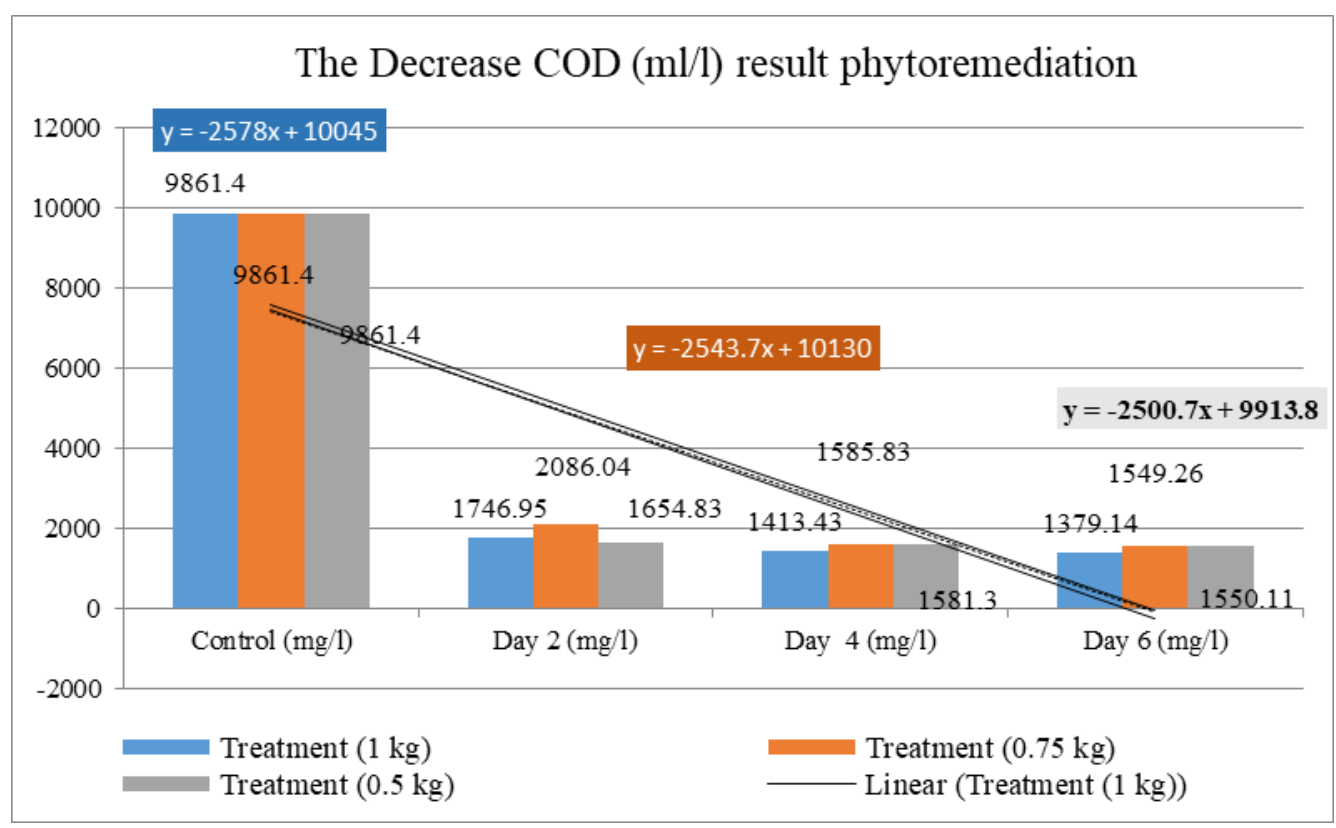

Figure 3 Trend evaluation decrease COD (mg/l) result phytoremediation

The results of the BOD parameter phytoremediation modeling at $1 \mathrm{~kg}$ treatment have a linear equation is $\mathrm{y}=-2578 \mathrm{x}+$ 10045, phytoremediation modeling on treatment $0.75 \mathrm{~kg}$ has a linear equation is $\mathrm{y}=-2543 \mathrm{x}+101130$, phytoremediation modeling at $0.5 \mathrm{~kg}$ treatment has the linear equation is $\mathrm{y}=-2500.7 \mathrm{x}+9913.8$. Based on all models, it has a negative value which shows that the Phytoremediation test of Echinodorus palaefolius (Water Jasmine) has succeeded in reducing the COD concentration, in fig 3 all treatments showed a decreasing graph. The best regression modeling results are at $1 \mathrm{~kg}$ treatment with the equation $\mathrm{y}=-2578 \mathrm{x}+10045$.

Table 2 shows that the BOD and COD concentrations will run out on a certain day. This analysis is only for degradation which has the best linear equation modeling, as follows:

Table 2 Prediction of the maximum degradation in the best BOD and COD treatment

\begin{tabular}{|l|l|l|l|l|}
\hline Day & \multicolumn{4}{|l|}{ The BOD-0.5 kg Phytoremediation analysis $(\mathbf{y}=-\mathbf{5 4 0 . 1 3 + 2 4 9 5 . 6})$} \\
\hline- & $(540.1)$ & 1.4 & 2.495 .6 & 1.765 .9 \\
\hline 2.0 & $(540.1)$ & 1.7 & 2.495 .6 & 1.554 .5 \\
\hline 4.0 & $(540.1)$ & 2.5 & 2.495 .6 & 1.165 .8 \\
\hline 6.0 & $(540.1)$ & 4.4 & 2.495 .6 & 95.1 \\
\hline 6.3 & $(540.1)$ & 4.6 & 2.495 .6 & $(5.2)$ \\
\hline Day & \multicolumn{4}{|l|}{ The COD-0.5 kg Phytoremediation analysis (y=--2578 $\mathbf{+ 1 0 0 4 5})$} \\
\hline- & $(2.578 .0)$ & 0.1 & 10.045 .0 & 9.861 .4 \\
\hline 2.0 & $(2.578 .0)$ & 3.2 & 10.045 .0 & 1.747 .0 \\
\hline 4.0 & $(2.578 .0)$ & 3.3 & 10.045 .0 & 1.413 .4 \\
\hline 6.0 & $(2.578 .0)$ & 3.4 & 10.045 .0 & 1.379 .1 \\
\hline 7.0 & $(2.578 .0)$ & 3.9 & 10.045 .0 & $(9.2)$ \\
\hline
\end{tabular}

The best treatment analysis for BOD parameters is on day 6.3 and the BOD concentration will run out with a residual value of $-5.2 \mathrm{mg} / \mathrm{l}$, while the COD parameter will run out on day 7 with a concentration value of $-9.2 \mathrm{mg} / \mathrm{l}$. 
Echinodorus palaefolius (Water Jasmine) has the ability to absorb and break down pollutants which can reduce the pollutant content itself quite well. Echinodorus palaefolius (Jasmine Air) is able to absorb oxygen and air from leaves, stems, and roots which are then released back into the area around the roots (rhizosphere). This happens because the Echinodorus palaefolius (water jasmine) has space between cells or airways as a transportation medium from the atmosphere to the roots. The physical results obtained in the field indicate that Echinodorus palaefolius (water jasmine) undergoes morphological changes. [11]

The process of absorption of substances contained in the test sample (Echinodorus palaefolius /water jasmine) is carried out by the ends of the roots with the tissue that occurs because of the attractive forces by air molecules present in plants. The absorption of organic and inorganic pollutants (BOD and COD parameters) is absorbed by plant roots in the form of ions that dissolve in the air, besides these ions, there are also nutrients that enter with the air stream. Substances that are absorbed by the roots will enter the trunk through the transport vessels (xylem), which will then be passed on to the stem and then the leaves. [12]. The Echinodorus palaefolius (Water Jasmine) plant if the water is limited, it will disrupt the photosynthesis process which causes damage to the leaves, the leaves will look brownish and even dry. The morphological condition of the leaves can be seen that before the treatment, the two plants had green leaves and looked fresh, but after the treatment, yellow spots were seen on the leaves of Echinodorus palaefolius (Water Jasmine) and some dried leaves on Echinodorus palaefolius (Water Jasmine). Changes in leaves can be caused by a high pollutant load which reduces the quality and quantity of chlorophyll in the leaves, causing the leaves to change color.[13]. Aquatic plants have three mechanisms in wastewater bioremediation. The first mechanism is phytostabilization as a process of immobilization of contaminants in water caused by groundwater flow through capillary pores. The second mechanism is rhizofiltration which is associated with the adsorption of rooted contaminants. The third mechanism is rhizodegradation in which the decomposition of pollutants in water by microbial activity in the roots of aquatic plants [14]. Roots owned by plants can affect the level of effectiveness of a plant in absorbing pollutants such as plants that float on the surface of the water have dense fibrous roots and many root hairs that have about the same size come out of the base of the roots that spread sideways and in all directions as well as branching with branch sizes that are not too different. The Echinodorus palaefolius (Water Jasmine) plant has a lot of fiber roots, which allows it to absorb organic and inorganic pollutants (BOD and COD parameters) and is more effective. The Echinodorus palaefolius (Water Jasmine) plant can be used as a phytoremediation plant because it has large hollow roots and stems which have the ability to supply large amounts of oxygen to the roots so that Echinodorus palaefolius (Water Jasmine) has the ability to process pollutants in water. [15]. In this process, plants that have absorbed organic and inorganic pollutants try to prevent poisoning due to pollutants to their cells by accumulating these toxins in certain organs, such as the roots, which will be translocated into the aerial tissue and enter the xylem and must pass through the casparian, this functions so as not to inhibit them. plant metabolism [16], however, if a very high pollutant load causes disruption of metablism and can cause the death of these plants one by one the leaves of Echinodorus palaefolius (Water Jasmine) change color gradually, the color change on the leaves turns yellowish and brownish, this is called With the symptoms of chlorosis, this is thought to be due to chemical activity between plants and water containing organic and inorganic pollutants [17]. Symptoms of chlorosis in plants are caused by exposure to high pollutants, exposure for too long and resulting in inhibition of chlorophyll synthesis. Symptoms of chlorosis can also be caused by organic and inorganic pollutants that inhibit the action of the enzymes that catalyze chlorophyll synthesis. [18]

The BOD parameter with $0.5 \mathrm{Kg}$ treatment had the best degradation ability compared to $1 \mathrm{~kg}$ and $0.75 \mathrm{~kg}$. Theoretically, if in an area there are more plants, the ability to degrade or phytoremediate pollutants (BOD and COD parameters) is possible homogeneous. Limited water conditions and the occurrence of very high pollutant loads cause the ability of photosynthesis to decrease and lead to chlorosis symptoms in Echinodorus palaefolius (Water Jasmine) plants. However, overall phytoremediatin Echinodorus palaefolius (Water Jasmine) against textile waste - Batik succeeded in reducing the BOD and COD concentrations well and significantly.

\section{Conclusion}

Based on the results of the research that has been done, it can be concluded that Echinodorus palaefolius (Water Jasmine) can reduce BOD (Biological Oxygen Demand) and COD (Chemical Oxygen Demand) levels in batik liquid waste. The weight treatment of Echinodorus palaefolius (Water Jasmine) plants used had a significant effect on reducing BOD (Biological Oxygen Demand) and COD (Chemical Oxygen Demand) levels in batik waste. Suggestions that can be given for further research are the need to select a more homogeneous sample on variations in age, number of roots and stem size. 


\section{Data availability}

All relevant data is in paper and supporting information files. This research will help researchers to reveal the critical area of the management of batik textile industrial wastewater by utilizing the biological agent is Echinodorus palaefolius (water jasmine) in the phytoremediation process. This research is expected to be a technological effort to reduce BOD (Biological Oxygen Demand) and COD (Chemical Oxygen Demand) from textile wastewater. Echinodorus palaefolius (water jasmine) as a biological agent in the phytoremediation process has been shown to reduce BOD and COD.

\section{Compliance with ethical standards}

\section{Acknowledgments}

The author is very grateful to the leadership of the Pekalongan environmental office and Dian Nuswantoro University so that this research can be carried out properly.

\section{Disclosure of conflict of interest}

All authors have stated that this activity is research without competing interests.

\section{References}

[1] Budiyanto S. The Impact of Batik Sewage Disposal Towards The Quality of Dug-Well Water in The Batik Industry Center of Jenggot Pekalongan City. Journal of Public Health for Tropical and Coastal Region. 2020; 2(2).

[2] Muslimah E, Soeparman S, Yanuwiyadi B, Riniwati H. A Comparison between the Environmental Impact of Each Batik Production Process. 2020.

[3] Nugroho P. The Role of Local Institutions in Industrial Cluster Development in Indonesia. 2014.

[4] Santoso I, Setyowati D, Priyanto A. Kali Loji Festival to Preserve River in Pekalongan City. Journal of Educational Social Studies. 2019; 8(1): 36-43.

[5] Sutjiningsih D. Water quality index for determining the development threshold of urbanized catchment area in Indonesia. International Journal of Technology. 2017; 1: 145-59.

[6] Rosyadi MK, Pujianti N, Setyaningrum R, Rahman F. Evaluation of Waste Water Treatment Toward Physical, Chemical, and Biology Parameters in WWTP Hasan Basry Banjarmasin, Indonesia 2016. Indian Journal of Public Health Research \& Development. 2017; 8(2): 142-6.

[7] Safauldeen SH, Abu Hasan H, Abdullah SRS. Phytoremediation efficiency of water hyacinth for batik textile effluent treatment. Journal of Ecological Engineering. 2019; 20(9).

[8] Handajani H, Widanarni W, Budiardi T, Setiawati M, Sujono S. Phytoremediation of Eel (Anguilla bicolor bicolor) rearing wastewater using amazon sword (Echinodorus amazonicus) and water jasmine (Echinodorus palaefolius). Omni-Akuatika. 2018; 14(2).

[9] Pandey VC, Bajpai O, Singh N. Energy crops in sustainable phytoremediation. Renewable and Sustainable Energy Reviews. 2016; 54: 58-73.

[10] Watson DG. Pharmaceutical analysis E-book: a textbook for pharmacy students and pharmaceutical chemists. Elsevier Health Sciences. 2020.

[11] Sari M, Hastuti E, Darmanti S. Potential of Water Jasmine (Echinodorus palaefolius) In Phytoremediation of Fe in Leachate Jatibarang Landfill. Biosaintifika: Journal of Biology \& Biology Education. 2019; 11(1): 55-61.

[12] Perdana MC, Sutanto HB, Prihatmo G. Vertical Subsurface Flow (VSSF) constructed wetland for domestic wastewater treatment. In: IOP Conference Series: Earth and Environmental Science. IOP Publishing. 2018.

[13] Das S, Mazumdar K. Phytoremediation potential of a novel fern, Salvinia cucullata, Roxb. Ex Bory, to pulp and paper mill effluent: physiological and anatomical response. Chemosphere. 2016; 163: 62-72.

[14] Saratale RG, Banu JR, Shin H-S, Bharagava RN, Saratale GD. Textile Industry Wastewaters as Major Sources of Environmental Contamination: Bioremediation Approaches for Its Degradation and Detoxification. In: Bioremediation of Industrial Waste for Environmental Safety. Springer. 2020; 135-67. 
[15] Solanki P, Narayan M, Srivastava RK. Effectiveness of domestic wastewater treatment using floating rafts a promising phyto-remedial approach: a review. Journal of Applied and Natural Science. 2017; 9(4): $1931-42$.

[16] Ghori Z, Iftikhar H, Bhatti. MF, Sharma I, Kazi AG, Ahmad P. Phytoextraction: the use of plants to re.move heavy metals from soil. In: Plant metal interaction. Elsevier. 2016; 385-409.

[17] Amdoun R, Bendifallah N, Sahli F, Moustafa K, Hefferon K, Makhzoum A, et al. Improving zinc phytoremediation characteristics in Salix pedicellata with a new acclimation approach. International Journal of Phytoremediation. 2020; 22(7): 745-54.

[18] Dubey R, Gupta DK, Sharma GK. Chemical Stress on Plants. In: New Frontiers in Stress Management for Durable Agriculture. Springer. 2020; 101-28.

\section{Author's short biography (optional)}

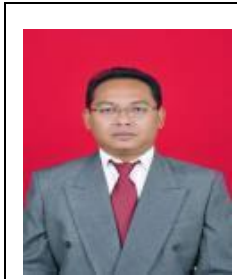

\section{Dr. Slamet Isworo}

Ph.D. Environmental Science

Lecturer at the Department of Environmental Health. Dian Nuswantoro University Semarang Indonesia Chairman of the Preparation of Environmental Impact Analysis REG LMH 786000152020 National Professional Certification Body

Competency Assessor No. REG MET 0003.003524.2016. No. 93000.2419. 10104229.2018 National Agency for Professional Certification, Indonesia. 